\title{
Land, Water and Wind Watershed Cycle: A strategic use of water, land and wind for climate change adaptation
}

\author{
Julian D. Hunt ${ }^{1}$, Walter Leal Filho ${ }^{2 *}$
}

\begin{abstract}
The increase in population and the improvement of life standards are stretching the boundaries between water-energy-land management and demanding innovative and holistic solutions. This article proposes an approach for increasing the water availability of two or more water basins taking into consideration land use and wind patterns, and was named Land, Water and Wind Watershed Cycle (L3WC). This approach can be applied to one watershed or a combination of watersheds. In the first case, if wind patterns blow mainly in the opposite direction of the main river flow, plantations with high water demand should be focused on the lowest part of the basin. The transpired moisture would then return to the basin with the wind and possibly increase the water availability of the basin. Applying this method to a series of basins, water is transposed from one basin to another, used for irrigated agriculture, returned to the atmosphere with evapotranspiration and pushed back to the basin where the water was extracted by the wind. Case studies of this methodology are presented in the São Francisco basin and between the Tocantins, Amazonas and Paraná basins and the São Francisco basin in Brazil. The São Francisco basin was the selected because it is located in a dry region, its flow has considerably reduced in the past decade and because the trade winds blow constantly from the ocean into the continent all year around. L3WC is a strategy to plan the allocation of water consumption in a watershed, taking into account wind patterns to support the sustainable development of a region. It has the potential of increasing water availability, and creating a climate change adaptation mechanism to control the climate and reduce vulnerability to climatic variations.
\end{abstract}

Keywords: Water management, Land use, Hydropower, Biomass, Climate Change Adaptation.

\section{1) Introduction}

Irrigation and cattle grazing, together with other processes that change water and land use, directly impact the local and regional climate. For example, the deforestation of the Amazon forest for cattle grazing in Brazil is contributing to the reduction in precipitation in most water basins in the country, which is resulting in environmental, economic and social impacts [1, 2, 3, 4, 5]. Land and water management could be performed in a way to increasresource availability, such as water and cultivatable land instead of a reducing then, as it is proposed in this paper.

\footnotetext{
${ }^{1}$ International Institute for Applied Systems Analysis (IIASA) - Schlossplatz 1 - A-2361 Laxenburg, Austria - Email: hunt@iiasa.ac.at

2 School of Science and the Environment, Manchester Metropolitan University, Chester Street M1 Manchester, UK \& Centre for Sustainable Development and Climate Change Management, Hamburg University of Applied Sciences, Hamburg, Germany- E.mail: w.leal@mmu.ac.uk.

* Corresponding author.
} 
Brazil has just gone through the worst drought in recorded history. The Southeast and Northeast regions have been especially affected during the years 2014 and 2015, and this trend persists in 2017 [6, 7]. The sectors most vulnerable to changes in climate in Brazil are the electricity generation and agriculture sectors. This is because hydropower generates around $70 \%$ of the country's electricity and the changes in climate over recent years has considerably reduced Brazil's hydropower production. Wind power is contributing to complement the reduction in hydropower generation, especially during the dry period, and its capacity is foreseen to reach $22 \mathrm{GW}$ by 2024. Solar power has less seasonal variations and is set to increase to $7 \mathrm{GW}$ by 2024 [8]. Another alternative to reduce the vulnerability of the electricity sector with great potential in Brazil is biomass [9]. However, the impacts of land and water use on water management and hydropower generation should be considered. For example, the water extracted to produce biomass could generate less economic returns, than if the water was used for hydropower. This happens in locations where the hydropower potential is very high. Thus, the economic and environmental analysis of biomass electricity generation should consider the reduction in hydropower potential. Climate change has been included in the strategic planning in Brazil [10]. However, the plan does not study how man-made use of land and water influences the Brazilian climate.

This study presents an approach to improve water and land used allocation, taking into consideration the direction of prevailing winds, with the intention of increasing the water availability of a basin or basins and for a better adaptation to changes in climate.

This paper is divided into 5 sections. Section 2 presents the two different approached for Land, Water and Wind Watershed Cycle. One focuses on an individual basin (Intrabasin L3WC) and the other on several basins (Interbasin L3WC). Section 3 presents two case studies in the Rio São Francisco basin in Brazil, one for each approach. Firstly, a probabilistic distribution of wind patterns in Brazil is presented, focusing especially on the São Francisco river. The Intrabasin L3WC case study is presented focusing on the comparison the water requirements and impact on hydropower and biomass electricity generation. A quick overview of the needs for water transposition in Brazil is presented. This is followed by a case study of the Interbasin L3WC, which is divided in four parts: the transposition of water, the consumption of water with irrigation, the return of the moisture with the wind and the use of L3WC as a climate change adaptation strategy. The benefits and challenges of the methodology are discussed in Section 4. Section 5 concludes the paper.

\section{2) Methodology: Land, Water and Wind Watershed Cycle (L3WC)}

This paper presents a water allocation strategy within a basin and among basins with the intention of increasing their overall water availability. This methodology should be applied to improve land and water use planning with the intention of increasing the services that could be extracted from the basin, such as water, energy, food, etc.

This concept has been divided into two methodologies. The first focuses on a single watershed and its presented in Figure 1 (a). In this case, the river flow and shape of a basin is compared with the predominant wind patterns. If the predominant wind direction in the watershed pushes water from downstream the basin to upstream the basin, then the basin can be considered for L3WC. If the wind blew out to the ocean than there would be no benefit to the nearby areas.

The other important aspect is the selection of the appropriate location for the water to be consumed. Plantations with the highest irrigation demand should be positioned in regions downstream the basin. This is already usually the case, given that downstream a 
watershed there is higher water availability. Following this water consumption allocation, the moisture transpired at the irrigated plantation will be carried back into the basin. This increase in moisture in the basin could consequently increase precipitation and its water availability. Note that for L3WC to work correctly, the wind direction should be predominantly against the direction of the basin, especially during periods when the water consumption for irrigation is at its highest. The combination of river flow and constant wind direction pattern is the main limitation for this methodology.

This is also convenient for bioenergy vs. hydropower electricity generation planning, given that the water for biomass plantation is extracted from downstream the basin, its impact in hydropower generation is reduced. Additionally, with the consequential increase in water availability in the basin with L3WC, hydropower generation in the basin should also increase. An example of Intrabasin L3WC is presented in Section 3.2.

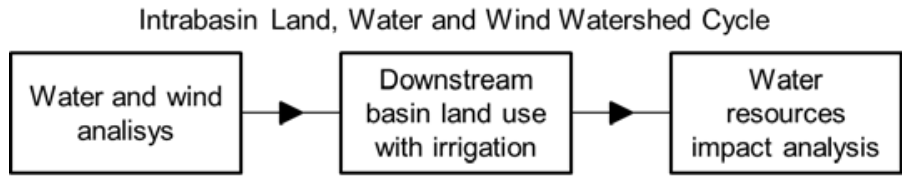

(b)

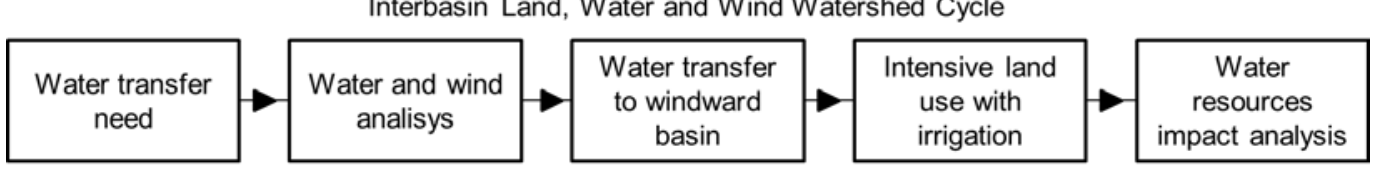

Figure 1: (a) Intrabasin and (b) Interbasin Water, Land, Wind Management Cycle potential analysis.

The second methodology involves water transposition between different basins and the return of the moisture with trade winds, as shown in Figure 1 (b). Firstly, the basin from where the water is extracted should have abundant water resources and the basin where water is transposed to should be water scarce. This is to justify the transposition projects, which are expensive and controversial due to environmental impacts. Similarly to Intrabasin L3WC, another important limitation for Interbasin L3WC is the constant wind patterns blowing the moisture in the opposite direction of the transposed water. If the wind blows predominantly in the opposite direction of the transposed water, then the project can be considered a L3WC.

Plantations with high irrigation demand should be positioned in the windward basin. The moisture transpired at the irrigated plantation returns to the atmosphere and is carried back into the original basin with the wind, increasing the water residence time in the two basins. This increase in moisture in the basins could consequently increase precipitation in the basins and their water availability. An example of Interbasin L3WC is presented in Section 3.4.

\section{3) Results: São Francisco Basin Case Study}

\section{1) Trade Winds in São Francisco Basin}

Figure 2 shows the yearly probability distribution of wind direction in the São Francisco basin at ground height [11]. The predominance of trade winds carries humidity from the Atlantic Ocean to the Brazilian countryside. These trade winds are predominant up to a height of 4,000 meters into the atmosphere [12]. This corresponds to the section in the atmosphere with the most humidity. According to Figure 2, considering the section 
of the São Francisco river where it meets the Atlantic Ocean, it can be seen that the trade winds and the São Francisco river flow are in opposite directions.

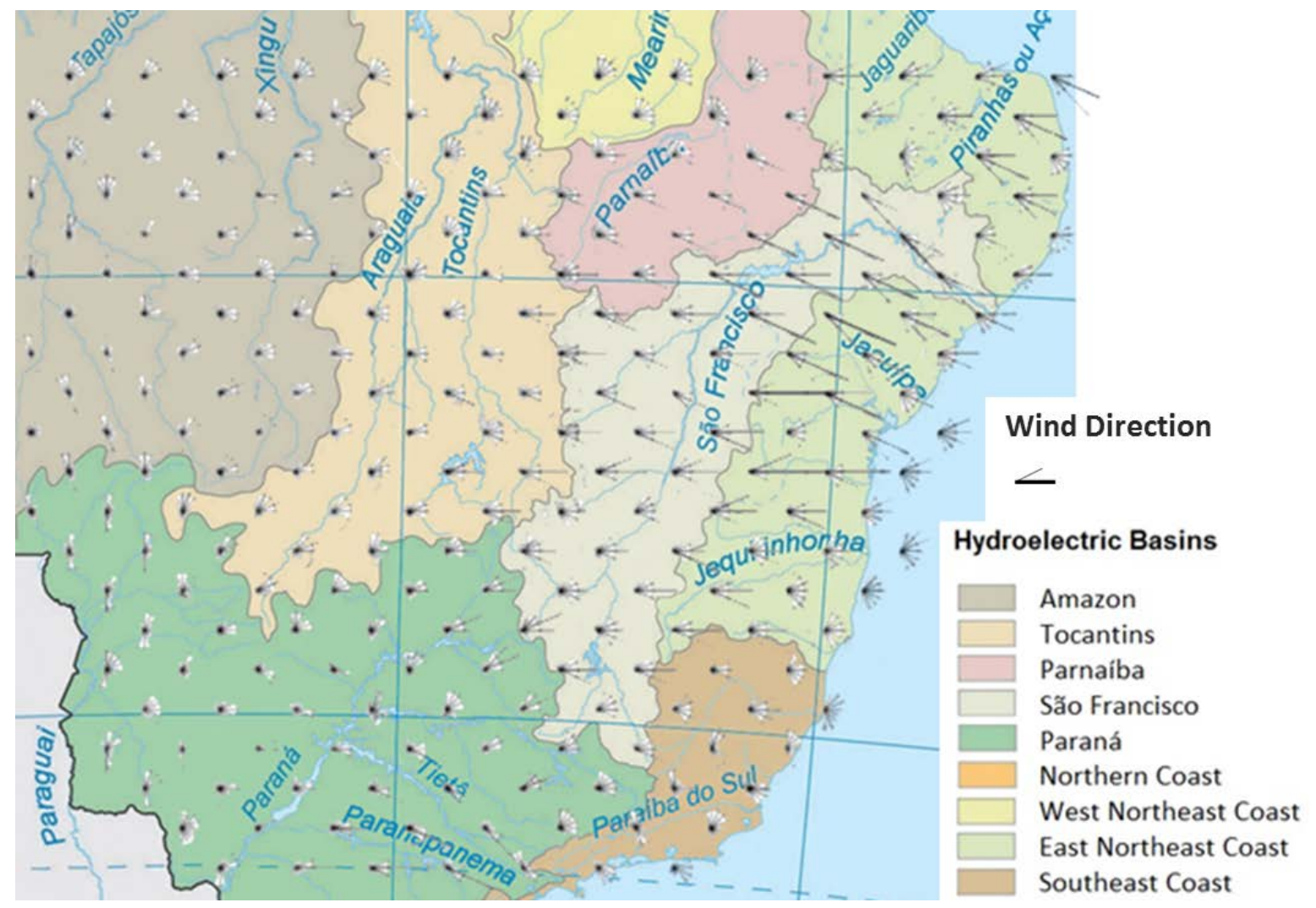

Figure 2: Probabilistic wind direction around the São Francisco basin [11].

Additionally to the trade winds, due to the proximity with the equator, another important aspect that contributes to the success of L3WC in Brazil is the fact that the Andes Mountains impede that the moisture entering the western side South America leaves the eastern side of South America. Thus, most of the moisture entering with the trade winds precipitates in the continent, mainly in the Amazon basin, and leaves the continent as river flow. Only a fraction of the moist air that enters with the trade winds leaves the continent, especially through the north or south of the continent. This is one of the reasons that the Amazon basin is the basin with the highest flowrate in the world of $130,000 \mathrm{~m}^{3} / \mathrm{s}$ on average [13]. In addition, this also increases the likelihood that the water transpired in the São Francisco river L3WC would precipitate in South America.

\section{2) Intrabasin L3WC}

This section presents a case study of Intrabasin L3WC in the São Francisco basin, as shown in Figure 1 (a). As it can be seen in Figure 2, the last section of the São Francisco river flows in the opposite direction as the wind patterns. This indicates that this location might be appropriate for Intrabasin L3WC. The other important aspect is to check if there is appropriate land for irrigated agriculture in the downstream section of the river. Then detailed modelling should be performed to study the impacts of the increased humidity of the basin on its climate (this task if out of the scope of this paper).

With the intention of increasing the water availability of the basin, plantations with high irrigation demand are introduced downstream the river basin. The evapotranspiration from the plantations increase the moisture in the air and the moisture 
is carried by the wind upstream the basin. This increase in humidity could contribute to an increase in precipitation. It should be noted that the water transpired near the mouth of the São Francisco river would not only precipitate in the São Francisco basin, but also in the Tocantins, Amazon, Paraná and other basins. However, this is beneficial when comparing to allowing the water to return into the Atlantic Ocean, as would contribute to the increase of water availability in Brazil. Climatic and hydrological models would be important to estimate the impacts of the watershed transposition cycle on the country's climate.

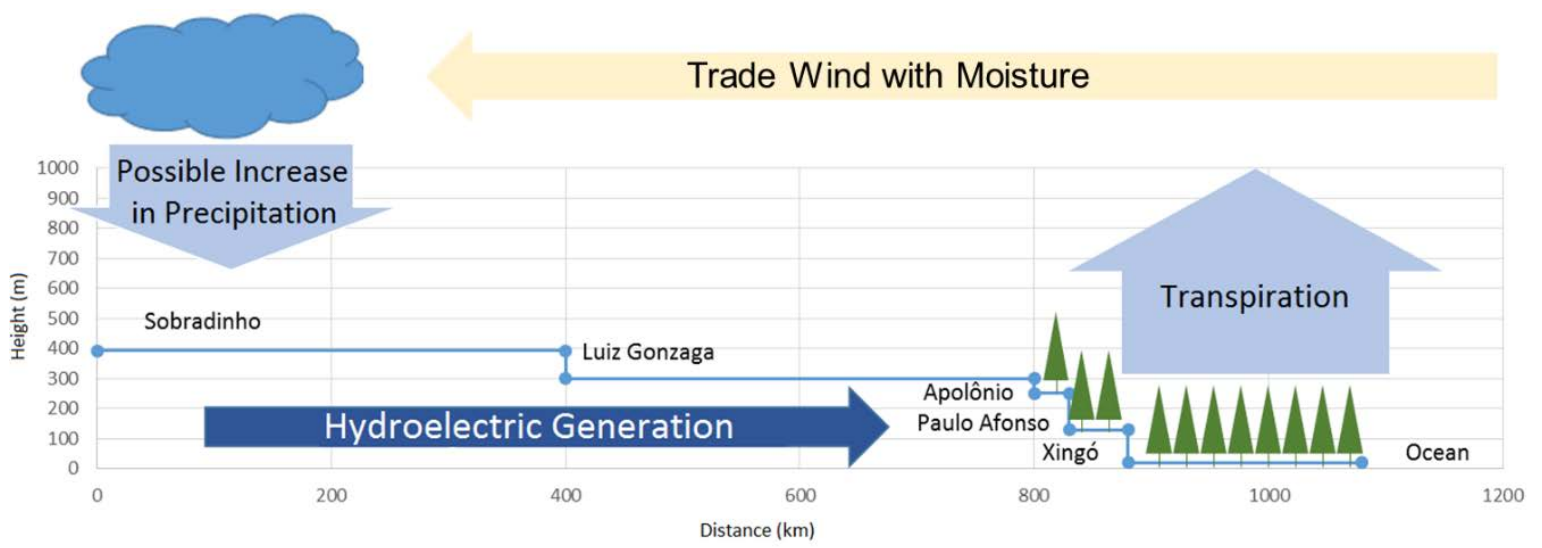

Figure 3: Diagram demonstrating the Transposition Cycle for the São Francisco river.

In order to optimize hydroelectric generation in the basin, biomass may be planted in locations with low hydropower potential. Biomass, especially eucalyptus, require large quantities of water. If the plantation is located at the São Francisco river mouth, the water will be used for irrigation and will be released into the atmosphere as moisture in the air. The strong trade winds carry the moisture back inland from the São Francisco river mouth, in the opposite direction of the São Francisco river flow. This moisture may increase rainfall in the São Francisco basin and, thus, it may create a partially closed artificial water cycle, as described in Figure 3, having a positive impact on hydroelectric generation in the basin, reducing the amount of water that returns to the ocean and increasing the water availability in Brazil.

In addition, the use of water for biomass electricity generation reduces the hydropower generation potential of the river where water is extracted. For example, in eucalyptus plantations near the Nova Ponte reservoir in Minas Gerais, the water consumed by the plantation turns into moisture in the atmosphere, which eventually precipitates in another location with a different hydroelectric generation potential. In this case, water used for growth of biomass would be removed from the reservoir of a hydroelectric cascade with a maximum generation head of 642 meters. If this moisture precipitates near the Ilha Solteira reservoir with a generation head of 199 meters, there will be a potential loss of hydroelectric generation of 442 meters. This hydroelectricity generation loss is equivalent to $20 \%$ of the electricity that would be generated when burning the biomass planted near Nova Ponte reservoir [9]. It would be better to plant biomass in low-altitude locations, with low potential for hydroelectricity generation, with the intention of reducing its impact on hydropower generation. Ultimately, if the biomass is located as suggested in this paper, it may result in an overall increase in hydropower potential and/or water availability in Brazil. 


\section{3) Water Transposition Needs}

The Araguaia basin is marked by periods of extreme droughts and floods throughout the year. It has a very flat topography and suffers from the intense silting of the river on the border between the states of Pará, Mato Grosso and Tocantins. This sedimentation restricts the flow of water, increasing the level of the Araguaia river from 6 to 11 meters during the flood period [13], which can cause severe floods in the Mid Araguaia basin. In a ten-year period, large scale floods happen causing huge impacts in the economy and in the environment. Severe floods happened in the years 2013, 2002, 1990 and 1980 [14, 13]. In February 2002, the flooded area in the Mid Araguaia region reached around $60,000 \mathrm{~km}^{2}$ [15].

The average flow of the main basins involved in this study to the Atlantic Ocean is $130,000 \mathrm{~m}^{3} / \mathrm{s}$ for the Amazon river, $8,000 \mathrm{~m}^{3} / \mathrm{s}$ for the Tocantins river, $12,000 \mathrm{~m}^{3} / \mathrm{s}$ for the Paraná river and for the São Francisco river the flow used to be 2,000 $\mathrm{m}^{3} / \mathrm{s}$ but has reduced to $700 \mathrm{~m}^{3} / \mathrm{s}$ in 2017 [13]. This current reduction in river flow is directly involved with the reduction on precipitation patterns and due to the increase in water consumption for irrigation. The São Francisco river basin has considerably less water than the other basins. Water from the other basins can be used to complement the need for water in the São Francisco river basin.

As shown in Figure 4, there is a reasonable amount of water in most locations of the Amazon, Tocantins, Xingú and Araguaia basins. On the other hand, the Northeast river basins suffer from critical or very critical water availability. A water transposition system would reduce the incidence of floods in the Araguaia Basin and reduce the impact of droughts in the São Francisco basin, functioning as a climate change adaptation measure. Projects have been developed for the transposition of water from the Tocantins river to the São Francisco river [16]. A committee of the Chamber of Deputies in Brazil (the lower Chamber in Parliament) is currently studying the possibility of implementing the transposition of water between the Tocantins and the São Francisco river [17].

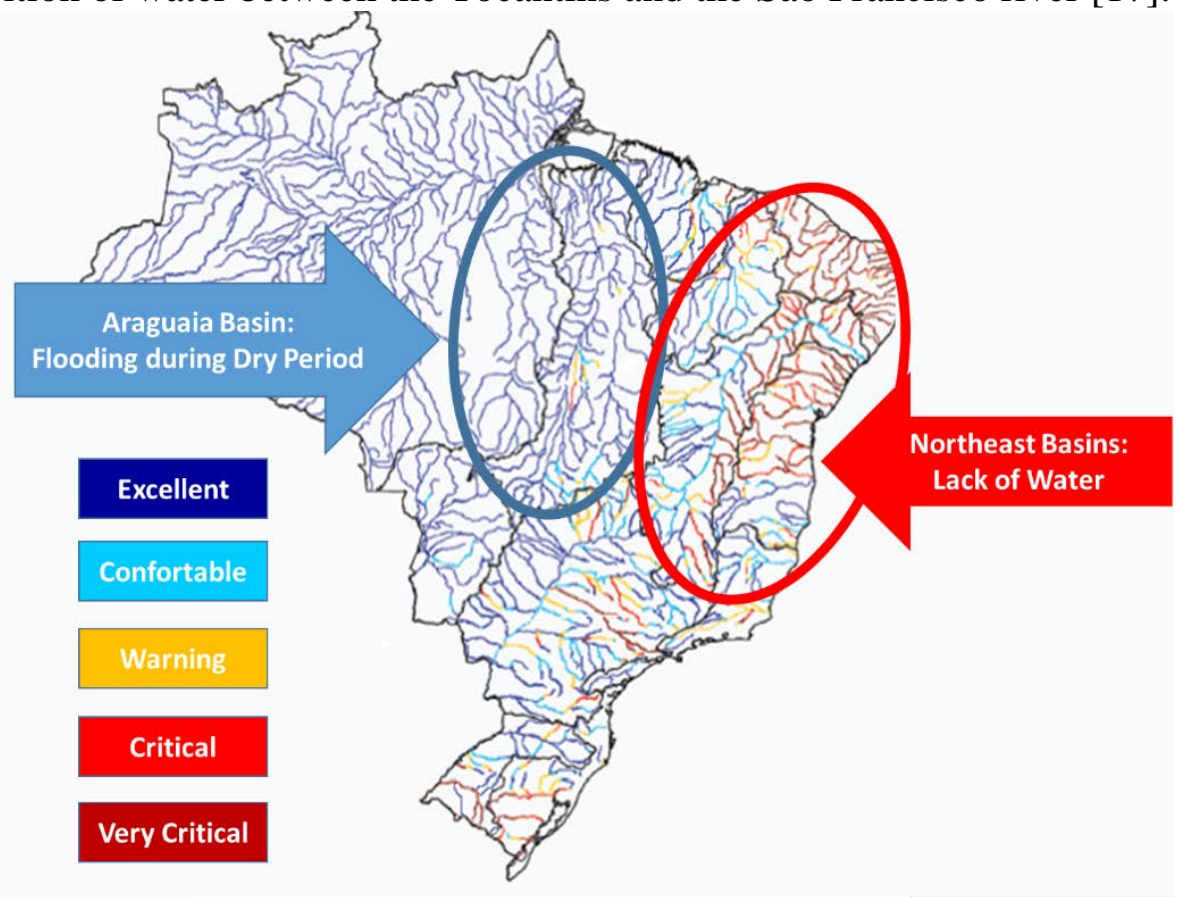

Figure 4: Water demand vs. availability in Brazilian river basins [18, 19]. 


\section{4) Interbasin L3WC Case Study}

This section presents a case study of Interbasin L3WC between the Amazon, Tocantins and Paraná basin and the São Francisco basin, as shown in Figure 6. As it can be seen in Figure 2, the wind blowing at the São Francisco basin is in the opposite direction of possible transposition projects from the Amazon, Tocantins and Paraná basins. This indicates that this location might be appropriate for Interbasin L3WC. The other important aspect is to check if there is appropriate land for irrigated agriculture in the São Francisco basin. Then, detailed modelling should be performed to study the impact of the increased humidity of all basins on the regional climate (this task is out of the scope of this paper).

\subsection{1) Transposition}

This article proposes four water transposition cycles between different basins as presented in Figure 6. The order of increasing complexity for transposition projects involves taking water from the Grande river, then Paranaiba river, then Tocantins, Araguaia and Xingu rivers and then Amazon river.

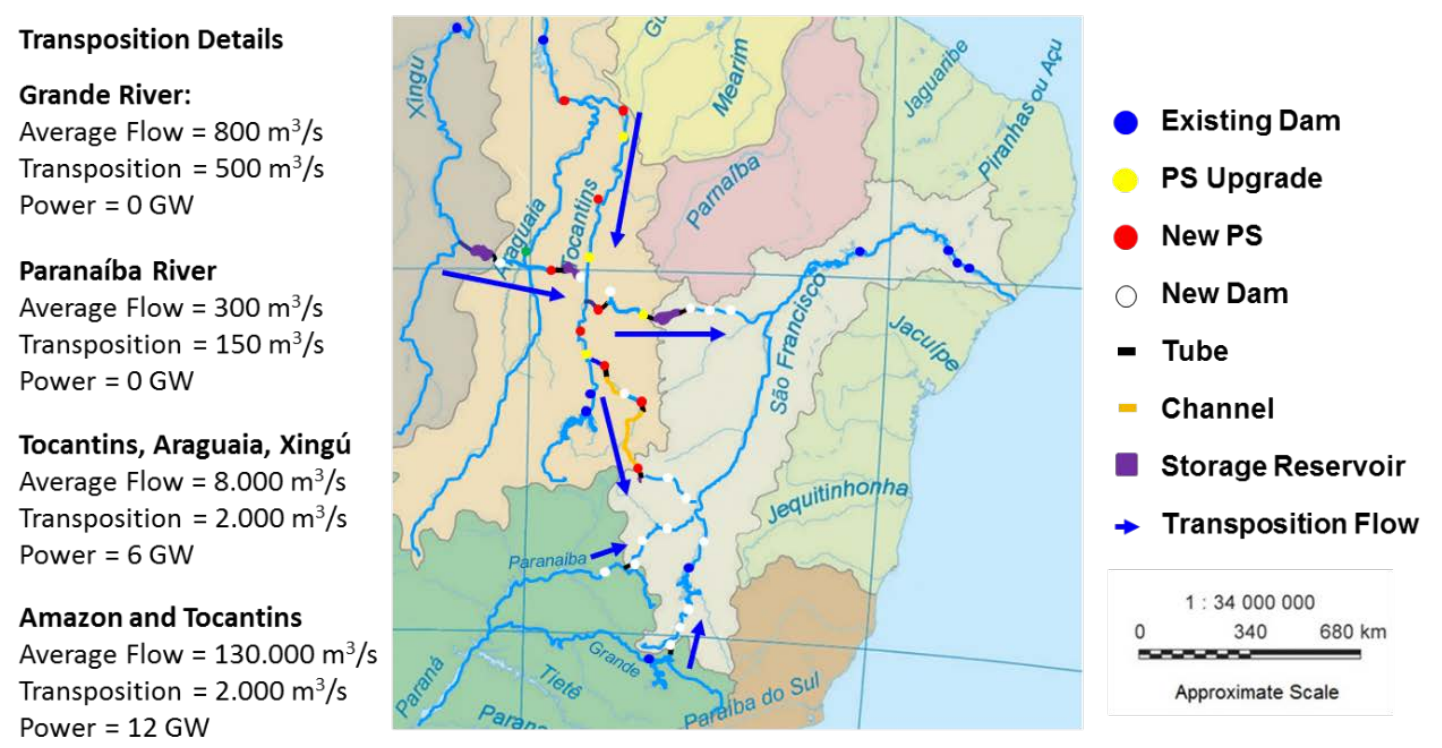

Figure 5: Water transposition projects proposed from the Paraná, Xingu, Araguaia, Tocantins, Amazon basin to the São Francisco basin.

The transposition of water from the Grande to the São Francisco river is not complicated. The Furnas reservoir has a storage capacity of $17 \mathrm{~km}^{3}$ and it is used to regulate the Grande river, which has an average flow of around $800 \mathrm{~m}^{3} / \mathrm{s}$. To connect the Furnas reservoir with the São Francisco river, a tube $15 \mathrm{~km}$ long is required. This tube would have a 100 meters head, which could be used for hydroelectric generation. Two more run-of-the-river dams should be built upstream the Três Marias dam and increase the hydropower generation head of the São Francisco river by an additional $80 \mathrm{~m}$. There is no energy needs for the transposition and the transposition would result in a similar or higher overall electricity generation. The estimated amount of water available for transposition is $500 \mathrm{~m}^{3} / \mathrm{s}$.

The transposition of water from the Paranaíba river, which has an average flow of around $300 \mathrm{~m}^{3} / \mathrm{s}$, to the São Francisco river requires the construction of a new dam and a tube $30 \mathrm{~km}$ long. This tube would have a 150 meter head, which could be used for 
hydroelectric generation. Three run-of-the-river dams should be built to increase hydropower generation head of the São Francisco river by an additional $100 \mathrm{~m}$. There is no energy needs for the transposition and the transposition would result in a similar or higher overall electricity generation. The estimated amount of water available for transposition is $150 \mathrm{~m}^{3} / \mathrm{s}$.

The transposition of water from the Xingu, Araguaia, and Tocantins rivers to the São Francisco river is not simple, but provides several benefits. Transposition of the Xingú river to the Araguaia river requires a $120 \mathrm{~km}$ canal with an average depth of $15 \mathrm{~m}$, which directs water from the Xingu river to a conventional storage reservoir in the Araguaia basin. This reservoir fills up during the wet season, when there is excess water in the Xingu river and generate electricity during the dry period with a maximum generation head of $210 \mathrm{~m}$. This water will be transposed into the Tocantins river and then to the São Francisco river.

To facilitate the transposition of water from the Araguaia river to the Tocantins river, it is important to control the flow of the Araguaia river in its head to reduce its seasonal flow and allow the transposition system to operate during the wet and dry periods. In order to achieve this, a channel will be created to stop flooding in the Araguaia river. A sedimentary basin storage dam will control the amount of water stored in the Mid-Araguaia sedimentary basin. Sedimentary basin storage intends to store water in the sandy ground and control the level of the groundwater with the dam. Flood control in the Araguaia basin will enable the economic development of the region and the increase in water storage will enable the transposition of water from the Araguaia river to Tocantins river throughout the whole year. The Araguaia basin has little investment in agriculture and other activities because it suffers annual flooding during the wet season due to its flat geological formation [20, 21].

The transposition project from the Araguaia to the Tocantins river will take place just after the Araguaia National Park at an altitude of $170 \mathrm{~m}$, where the Araguaia and Javaés rivers converge. The transposition will require a $140 \mathrm{~km}$ canal with an average depth of $15 \mathrm{~m}$ and a tube $80 \mathrm{~km}$ long with pumping facility to Lajeado reservoir at an absolute height of $210 \mathrm{~m}$.

The northern transposition Project from the Tocantins river $(210 \mathrm{~m})$ to the São Francisco river requires a $60 \mathrm{~km}$ canal with an average depth of 20 meters, tubes with 20 $\mathrm{km}$ and pumping facility to a run-of-the-river dam at an absolute height of $390 \mathrm{~m}$. Following, another tube $60 \mathrm{~km}$ long with pumping facility to a seasonal-pumped-storage reservoir, with its level varying between 750 and $650 \mathrm{~m}$ to store water and energy. In addition, two dams in the São Francisco basin will recover some of the energy used for pumping. The Northern Transposition Project has a $1.500 \mathrm{~m}^{3} / \mathrm{s}$ flow capacity.

The southern transposition project from the Tocantins river to the São Francisco river will require three pumping facilities with $20 \mathrm{~km}$ tube and $200 \mathrm{~km}$ channel. Then a $35 \mathrm{~km}$ long tube will connect the channel to the São Francisco basin. Part of the electricity used to pump the water will be generated at the other end of the transposition. It is estimated that for a $2.000 \mathrm{~m}^{3} / \mathrm{s}$ transposition flow would require $6 \mathrm{GW}$ of pumping capacity.

Figure 5 presents a possible transposition project bringing water from the Amazon river into the São Francisco river using the Tocantins river as a channel. The transparent blue arrow represents the predominant trade wind direction, the solid blue lines presents the direction of the transposed water. This is the transposition alternative with the lest water conflict issues, as the Amazon river has abundant water resources. For this process to happen four dams will have to be built on the Tocantins river and new pumped-storage turbines will have to be installed in the dams. These pumped-storage turbines would be able to operate both as pumps and as turbines to generate electricity. The installed pump- 
storage capacity will be gradually increased with the altitude in the Tocantins river. The upper section of this transposition process is similar to the northern transposition Project mentioned above.

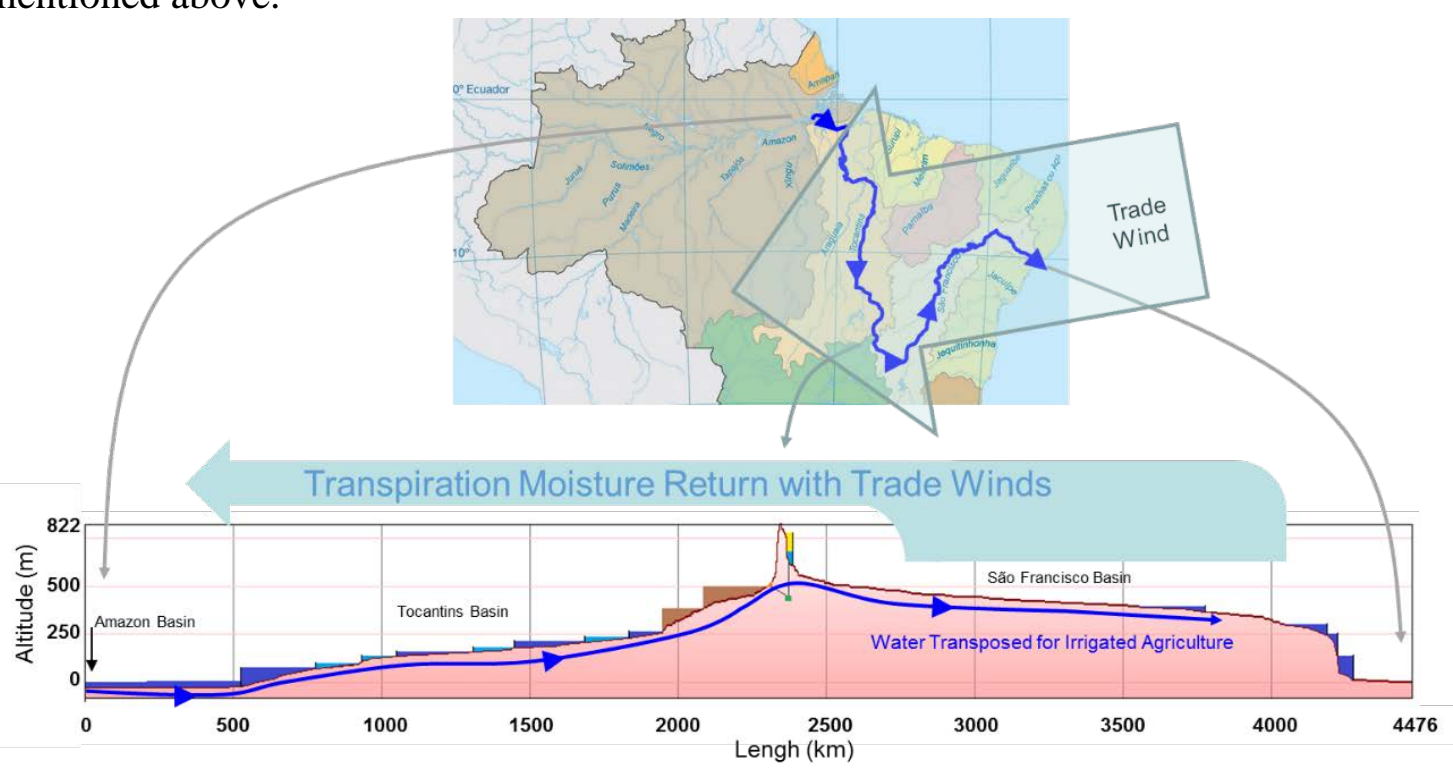

Figure 6: Land, Water and Wind Watershed Cycle between the Amazon an São Francisco basin, through the Tocantins river [22].

Additionally, this article suggests the operation of the Sobradinho reservoir at its lowest level. The Sobradinho reservoir has a maximum flooded area of around 4,200 $\mathrm{km}^{2}$ in the driest location of Brazil, which results in an evaporation of an average of $170 \mathrm{~m}^{3} / \mathrm{s}$ of the São Francisco river flow [23].

\subsection{2) Water Consumption with Irrigation}

The second stage of the Land, Water and Wind Watershed Cycle involves the consumption of the water and turning it into moisture within the watershed. This can be done with land irrigation for food production or biomass plantations, power generation cooling processes, industrial processes, and other uses of water, such as transport, leisure, human consumption, environment, etc. Assuming that water made available from the four transposition projects proposed is more than enough to supply the demand for food production and other processes, this article proposes the use of water for irrigated biomass plantations (i.e. Eucalyptus) to illustrate the process.

Eucalyptus has a high productivity (more than $60 \mathrm{~m}^{3} / \mathrm{ha} / \mathrm{y}$ has been reported [24]) and energy characteristics (wood density and heat capacity [25]). The tree genus has been acclaimed as one of the best options for energy production due mainly to the large number of species, which enables wide ecological distribution, favoring its introduction in various regions with different soil and climatic conditions [26]. The data used to estimate the water transpiration and biomass production assumed the Eucalyptus Grandis species planted with a spacing of $3 \mathrm{~m} \times 3 \mathrm{~m}$ at the Três Lagoas Municipality [27].

Assuming that the annual average precipitation in the São Francisco basin is 1,200 $\mathrm{mm}$ and an water for irrigation of 12,000 $\mathrm{m}^{3} /$ ha.year [28], and an average growth rate of $60 \mathrm{~m}^{3} /$ ha year [29] (due to high solar radiation and water availability with irrigation). Thus, an approximately $100,000 \mathrm{~km}^{2}$ of irrigated plantation area would be required to consume the additional $4,000 \mathrm{~m}^{3} / \mathrm{s}$ of water transposed to the São Francisco river. 
If all this area were used for the cultivation of eucalyptus, it would result in a production of 63 billion $\mathrm{m}^{3}$ of eucalyptus per year. If this eucalyptus were used for electricity generation, it would be able to generate around $90 \mathrm{GW}$ of electricity at a $90 \%$ capacity factor. Much more than the average electricity demand in Brazil (65 GW). The planted biomass could be transported by waterway to the mouth of the São Francisco river and exported to other countries. Alternatively, the irrigated land could produce sugarcane, corn, cotton and other crops (giving preference to crops that consume a lot of water).

\subsection{3) Moisture Recycle with the Wind}

The third stage of the L3WC consists of the moisture returning to the basin where the water originally came from. Alternatively, L3WC could be used to direct the water to a different location where there is low humidity and lack of water. This is the most critical aspect required for a successful L3WC system. There are limited locations in the world where wind patterns are constantly blowing in the same direction and where the L3WC can be applied.

In the case study presented in this article, the additional moisture in the São Francisco atmosphere, resulted from the water transposition and water transpiration/consumption, is carried by the trade winds to the Tocantins, Amazon and Paraná basins, as shown in Figure 2, with wind speeds of yearly average of $11 \mathrm{~m} / \mathrm{s}$ at $1,400 \mathrm{~m}$ absolute height $[30,31]$. These are the basins from where the transposed water was taken from. Thus, the moisture returns to their original basins resulting in a partially closed hydrological cycle.

\subsection{4) Climate Change Adaptation with L3WC}

L3WC is an important climate change adaptation methodology. Apart from removing water, from where it causes problems and taking it to a region with lack of water, the water consumed would return to where it was originally from increasing the overall water availability of both basins. For example, if a basin is suffering with a drought, there will be an increase in irrigation to maintain the high agricultural production rate. The increase in irrigation would increase the humidity of the basin and, thus, partially mitigate the impacts of the drought. Alternatively, if there is a period with high precipitation and flooding, there will be a reduction in demand for irrigation and, thus, the contribution of the L3WC to the intensification of the flooding conditions reduces.

In order to give a rough estimate of the impact of the L3WC on Brazil's climate, the river flow of the Amazon, Tocantins, Paraná and São Francisco rivers combined $\left(152,000 \mathrm{~m}^{3} / \mathrm{s}\right)$, is compared with the transposition flow presented in this paper of 4,000 $\mathrm{m}^{3} / \mathrm{s}$. In addition, assuming that the moisture entering the continent with the trade winds precipitates, the impact of the L3WC would be around $2.6 \%$ of the humidity entering the continent, which is rather small. However, if the L3WC transposed flow could be increased to $40,000 \mathrm{~m}^{3} / \mathrm{s}$ (especially extracting water from the Amazon and expanding intensive irrigated agriculture to the entire Northeast region), the impact would be equivalent to $26 \%$, which is quite reasonable. In order to estimate the real impact of L3WC, climate models should be developed with the intention of better predicting the changes in climate with the operation of L3WC projects in different climatic scenarios, such as drought or floods. 


\section{4) Discussion}

The transfer of water between river basins is a very debatable issue because of the high costs involved and the multiple interests in the use of water. This study presents a new approach to transposition with positive and negative aspects. These aspects are mentioned below:

a) Positive:

1) Increase in water availability in the São Francisco basin and other basins.

2) Increase the energy storage, electricity demand side management (pump water when there is excess electricity generation) and energy security in Brazil, which allow the increase in renewable sources of energy, such as wind and solar [32].

3) Increase agricultural efficiency in the São Francisco basin due to irrigation.

4) Facilitate the construction of flood control systems in the Araguaia basin, which prevents the development of the region [20, 21].

5) Increase in precipitation in the São Francisco basin due to the additional moisture in the atmosphere.

b) Negative:

1) High implementation costs.

2) Environmental impacts with the construction and operation of the transposition projects and with the intense irrigated plantations.

3) Conflicts resulted from the multiple uses of water and multiple stakeholders.

\section{4) Conclusions}

This article introduced a new mechanism named Land, Water and Wind Watershed Cycle aiming to increase the water availability of a basin or a region. The L3WC is an artificial water cycle generated by the transposition of water to another basin. This water is consumed in plantation irrigation and then returned by the strong trade winds to the location from where it was removed. Four examples of water transposition processes to the São Francisco river have been considered. The direction of the wind along the São Francisco basin carries moisture into Brazil, in the opposite direction of the transposed water. This would increase the residence time of the water in the continent, which would increase the availability of water in Brazil.

It was found that an approximately 100,000 km2 of irrigated eucalyptus plantation area would be required to consume 4,000 m3/s of water from the São Francisco river. The resulting biomass produced would be able to generate $90 \mathrm{GW}$ of electricity at a $90 \%$ capacity factor. In addition to increasing irrigation in Brazil, this mechanism can be used to assist adaptation to climate change, as it would change the spatial distribution of water in Brazil, possibly increasing its water availability. This would have a positive impact on the country's climate, which is in degradation.

For future work and in line with modern trends in climate change adaptation [33], it is necessary to create additional climate and hydrological models in order to estimate the moisture dispersion from the São Francisco basin. Eventually, it could be shown that the Land, Water and Wind Watershed Cycle may not be easily implemented. However, it is important to understand this mechanism and that changes in land and water use have 
direct impacts on the climate. This knowledge could then be used to improve uses of land and water with the intention of creating communities more resilient to changes in climate.

\section{References}

[1] E. Davidson, A. De Araüjo, P. Artaxo, J. Balch, I. Brown, M. C. Bustamante, M. Coe, R. Defries, M. Keller, M. Longo, J. Munger, W. Schroeder, B. Soares-Filho, C. Souza Jr. and S. Wofsy, “The Amazon basin in transition,” Nature, vol. 481, no. 7381, pp. 321-328, 2012.

[2] J. Lean and D. Warrilow, "Simulation of the regional climatic impact of Amazon deforestation,” Nature, vol. 342, no. 6248, pp. 411-413, 1989.

[3] D. Spracklen, S. Arnold and C. Taylor, "Observations of increased tropical rainfall preceded by air passage over forests,” Nature, vol. 489, no. 7415, pp. 282-285, 2012.

[4] A. G. V. Henderson-Sellers, "Possible climatic impacts of land cover transformations, with particular emphasis on tropical deforestation," Climatic Change, vol. 6, no. 3, pp. 231-257, 1984.

[5] J. Júnior, J. Tomasella and D. Rodriguez, "Impacts of future climatic and land cover changes on the hydrological regime of the Madeira River basin,” Climatic Change, vol. 129, no. 1-2, pp. 117-129, 2015.

[6] R. Barifouse, "Sudeste pode 'aprender com Nordeste a lidar com seca'," 2014. [Online]. Available:

http://www.bbc.com/portuguese/noticias/2014/08/140820_crise_agua_nordeste_sudeste_rb.

[7] A. Vasco, "Indicadores de Alteração Hidrológica: O Declínio das Vazões no Baixo Rio São Fracisco,” in Universidade Federal de Sergipe, São Cristovão, 2015.

[8] Empresa de Pesquisa Energética, “Plano Decenal de Expansão de Energia 2024,” EPE, Rio de Janeiro, 2015.

[9] J. Hunt, V. Guillot, M. Freitas and R. Solari, "Energy crop storage: An alternative to resolve the problem of unpredictable hydropower generation in Brazil,” Energy, vol. 101, pp. 91-99, 2016.

[10] B. M. o. Environment, "National Adaptation Plan to Climate Change: Sectoral and Thematic Strategies, Volume II,” Brazilian Ministry of Environment, Brazilia, 2016.

[11] O. A. C. Amarante, M. Brower, J. Zack and A. L. Sá, “Atlas do Potencial Eólico Brasileiro,” CEPEL, Brasília, 2001.

[12] Windyty, [Online]. Available: https://www.windyty.com. [Accessed 11 July 2016].

[13] Agencia Nacional de Águas, "Hidroweb,” Sistema Nacional de Informações sobre Recursos Hídricos, [Online]. Available: http://www.snirh.gov.br/hidroweb/. [Accessed 1707 2016].

[14] P. Dias, “Análise Espacial Aplicada à Delimitação de Áreas Úmidas da Planície de Inundação do Médio Araguaia,” Universidade Federal do Mato Grosso, Cuiabá, 2014.

[15] Instituto de Pesquisas Hidráulicas, “Hidrologia de Grande Escala,” IPH/UFRGS, [Online]. Available: https://www.ufrgs.br/hge/modelos-e-outros-produtos/mgb-iph-propagacaoinercial/. [Accessed 1707 2016].

[16] F. Mamede, P. Garcia and W. Sousa Júnior, “Análise de Viabilidade Sócio-EconômicoAmbiental da Transposição de Águas da Bacia do Rio Tocantins para o Rio São Francisco na Região do Jalapão/TO,," Conservation Strategy Fund, Conservation International do Brasil, Instituto Internacional de Educação do Brasil, Brazilia, 2002. 
[17] C. E. -. T. d. R. S. Francisco, “Apresentação do Plano de Integração de Bacias e sobre o estágio em que se encontram os eixos da obra de transposição nos Estados de Minas Gerais, Bahia e Pernambuco,” Brazilian Chamber of Deputies, Brazilia, 2015.

[18] Agência National de Águas, "Disponibilidade e Demandas de Recursos Hídricos no Brasil,” ANA, [Online]. Available: http://arquivos.ana.gov.br/planejamento/ estudos/sprtew/2/2ANA.swf. [Accessed 1707 2016].

[19] Agência Nacional de Águas, “Balanço Hídrico Quantitativo,” ANA, [Online]. Available: http://portal1.snirh.gov.br/ana/apps/webappviewer/index.html?id=ac0a9666e1f340b387e80 3 2f64b2b85a. [Accessed 1707 2016].

[20] M. E. Santos, "Estudo Econômico do Rio Araguaia - Região de Aruanã pela demanda turística,” Universidade de Goiás, Goiânia, 2006.

[21] J. A. Costa, "Desenvolvimento de um sistema de alerta de enchente aplicado aos planos de defesa civil em áreas de risco no Estado do Pará utilizando sistema de informações geográficas (SIG), Caso: Cidade de Marabá,” Universidade Federal do Pará, Belém, 2012.

[22] Operador do Sistema Nacional, “Operação Diária do Operador do Sistema Nacional,” ONS, 2015. [Online]. Available: http://www.ons.org.br/publicacao/ipdo/.

[23] Operadora Nacional do Sistema Elétrico, “Evaporação Líquidas nas Usinas Hidrelétricas,” ONS, Rio de Janeiro, 2004.

[24] L. Couto, I. Nicholas and L. Wright, "Short rotation eucalypt plantations for energy in Brazil,” in IEA Bioenergy, Viçosa, 2011.

[25] W. Chen, P. Kuo, L. S. and W. Wu, "Thermal characterization of oil palm fiber and eucalyptus in torrefaction,” Energy, vol. 71, pp. 40-48, 2014.

[26] L. Couto and M. Müller, "Florestas Energeticas no Brasil,” in Biomassa para Energia, São Paulo, UNICAMP, 2008, pp. 93-111.

[27] I. Sartorio, “Avaliação e Modelagem do Crescimento de Florestas Energeticas de Eucalipto Plantadas em Diferentes Densidades,” Universidade Federal do Paraná, Curitiba, 2014.

[28] Confederação da Agricultura e Pecuária do Brasil, "Plantio de eucalipto no Brasil: Mitos e verdades,” CNA, Brasilia, 2011.

[29] I. P. Sartório, "Avaliação e Modelagem do Crescimento de Florestas Energéticas de Eucalipto Plantadas em Diferentes Densidades,” Universidade Federal do Paraná, Curitiba, 2014.

[30] Centro de Referência para Energia Solar e Eólica, “Atlas do Potencial Eólico do Estada da Bahia,” CEPEL, Rio de Janeiro , 2013.

[31] Topographic-map, “Brasil,” Topographic-map.com, [Online]. Available: http://ptbr.topographic-map.com/places/Brasil-3559915/. [Accessed 1707 2016].

[32] J. D. Hunt, M. A. Freitas and A. O. Pereira Junior, "Aumentando a Capacidade de Armazenamento Energético do Brasil," in IX Congresso Brasileiro de Planejamento Energético, 25 a 27 de Agosto, Florianópolis, 2014.

[33] W. Leal Filho, Handbook of Climate Change Adaptation, Berlin: Springer, 2015. 